\title{
AN UNDERWORLD TAILORED TO TOURISTS: A DRAGON, A PHOTO-MODEL, AND A BIOINDICATOR
}

\author{
Ivo Lučić
}

\begin{abstract}
The history of studies of a subterranean tailed amphibian, known as the olm or proteus (Proteus anguinus), is a colorful indicator of the changing view of the world beneath our feet. Throughout history, the underground has been presented as other worldly inhabited by life not of this world. At first, caves were the habitat of ghosts and spirtits, and then as a symbol for hell with all its attributes. The olm, in light of this prominant worldview, is discussed here, in which its status changed from that of a mythical dragon, to a photo-model, to a biological indicator of environmental health. The mix of these roles, with which the modern notion of this animal is presented, is mostly generated by the experience of tourguides in Postojna Cave in Slovenia. For a long time, Postojna was the only place that the wider public recognized as a home for proteus. This clearly shows the need to analyze the popular media constructions of environment.
\end{abstract}

\section{INTRODUCTION}

The first recognized cave-adapted animal, the olm, was described by Viennese zoologist J. N. Laurenti and named Proteus anguinus in 1768. Media interest in the olm has intensified in recent years. In mid-2016, it became one of the most frequent cave-related topics in the public media. This happened not only in local media from the Dinaric Karst region, where the olm is a local phenomenon, but included media from around the world, from Canada to Australia and Eastern Asia. Particular interest was raised by the hatching of olm in the Postojna Cave in Slovenia vivarium in early 2016 and reached its peak at the end of May and the beginning of June of that year. At the same time, images and videos of olm hatching were published for the first time. In this article, I try to provide answers to the question of how the media perceived the Postojna Cave olm in their coverage and why.

Dinaric Karst, which occupies half of the Adriatic Sea bed and areas to the east and north of the Adriatic Sea, is the largest karst area in Europe (Kranjc, 2003). It is the first area where karst was scientifically described and researched, and is the best known hot-spot of subterranean biodiversity in the world (Sket, 1999; Culver and Sket, 2000). Its most famous representative, the olm (Fig. 1), is one of the central figures in the history of karst research.

\section{Subject and Method}

In this article, I do not venture into empirical research on the frequency of media reports, nor do I deal with quantification of any aspect of that phenomenon. Rather, I focus on perceiving and defining key narratives or images of the olm that appeared and that are common to most of the articles and explain their background. First, I present the history of research and knowledge of the olm followed by the analysis of this knowledge based on cultural models or worldviews. Then an explanation is provided for the media construction of reality (i.e., which of the scientific facts was valued and accepted as a standard form of this phenomenon by the communications community). In other words, on what did the media base its image of the olm? The fourteen most visible articles revealed by an Internet search, regardless from where in the world they originated, were taken into consideration. The most visible image presents the olm as a descendant of the dragon; the media titillated their readers with claims that actually "young dragons" have hatched in Postojna Cave. More than half of the articles contained the claim that the olm was a young dragon in their title (AFP, 2016; Anonymous, 2016; Fleur, 2016; Fox News, 2016; Gili, 2016; Hrala, 2016; Photopoulos, 2016; Tan, 2016; Vrdoljak, 2016; Webb, 2016; McKie, 2017) and this term appears in the articles several times (Figs. 2A, 2B). For instance, when explaining the mythological history of the olm, The Guardian (McKie, 2017) mentions the word "dragon" seven times and uses it as a synonym for the olm. Others have done a similar thing, with frequent use of the word "dragon." I do not claim that the media wanted to literally present the olm as a dragon, which will be discussed later, but it was a feature that proved to be of extraordinary importance in its media presentation.

Unlike this dominant mythological image that originates without scientific knowledge, the other two images of the olm rely on scientific facts. One is based on the natural sciences: the olm is a living being, an aquatic salamander and a topic of biological research. When depicting the development of the knowledge about the olm in the past, the media use the historical science as well. This image remains factually credible however, since everything is happening in a tourist cave, with regard to business market conditions, it becomes a dimension of the tourist attraction itself.

Environmental science prevails in the third image of the olm, but it includes social and ethical aspects, as well. The olm is perceived as a part of an endangered environmental system. Hence, the survival of such a vulnerable spe-

'Dubrava 256 d, 10000 Zagreb, Croatia, ivolucic@gmail.com 


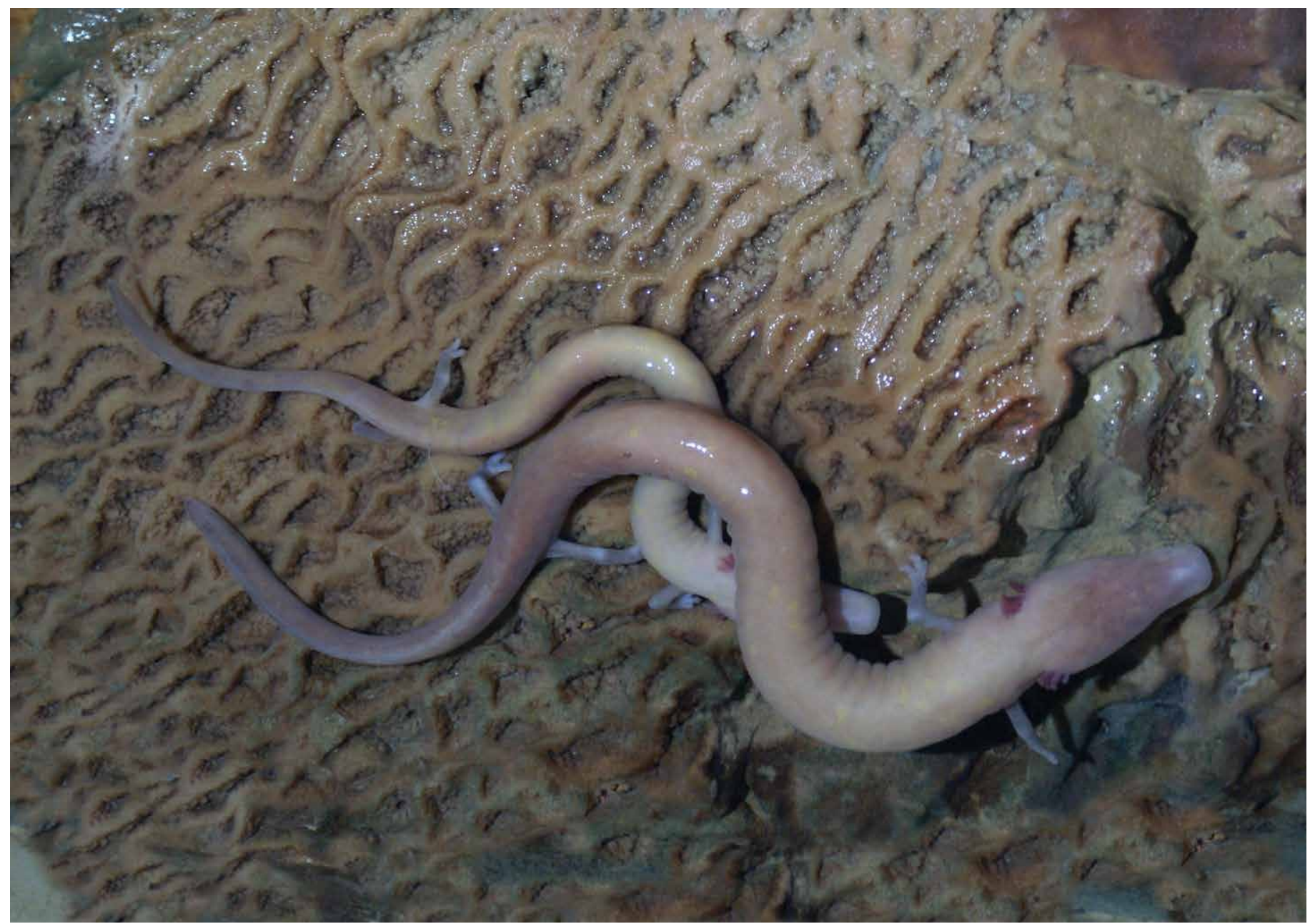

Figure 1. OIms.

IRILOBITES

In a Slovenian Cave, Hoping

for a Batch of Baby 'Dragons'

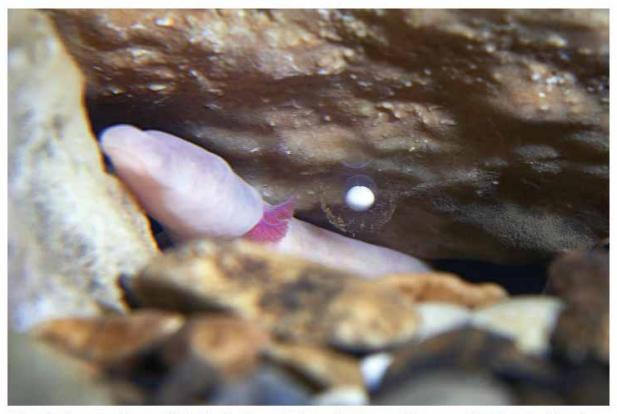

By Nicholas St. Fleur

Feb. 5. 2016

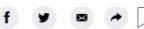

Creatures resembling dragons dwell deep within the caves of Slovenia. And now with the help of biologists, a new brood is set to hatch at an umisual aciorium arrescible by underground is in.
A female olm, someti
Slovenia, $1 z$ tros
Rare 'Baby Dragons' Recorded Hatching in Ancient Slovenian Cave

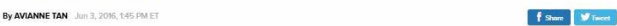

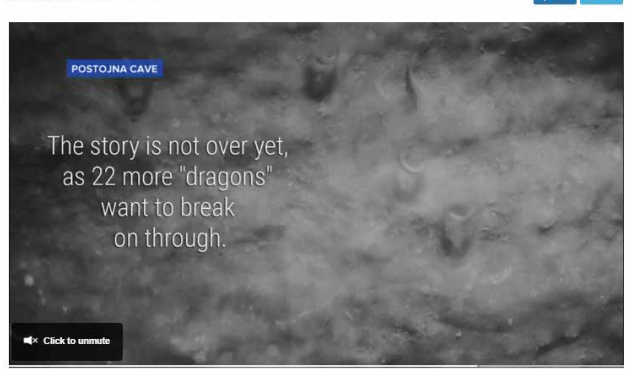

WATCH | Rare 'Baby' Dragons' Hatch in Anclent Cave

(9)

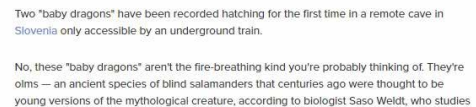

Figure 2A. Media coverage of proteus hatching: New York Times, 2B ABC news (screenshots).

cies becomes imperative for the protection of nature in general: "Olms are a flagship species [in] need of protection. If there's too much pollution, they will disappear," warned Saso Weldt, a biologist working at Postojna Cave (Fleur, 2016).

All three images are nicely visible in the article by local Al Jazeera Balcans (Vrdoljak, 2016). In it, the olm is referred to as: (a) small dragons, whose life (b) like that of the movie stars, is lived with the constant presence of a camera and (c) an animal that requires clean water to survive, otherwise it would become extinct. Other articles on the olm, which appeared in the regional media (Šimičević, 2012; Vecernji list, 2017) unrelated to this campaign, contain similar ideas. Because the media often reach for arguments in historical reviews, I will present the history of proteus research first. 


\section{Living World of the Underground seen through the Eyes of Traditional Culture}

For centuries, the olm was the only known inhabitant of the karst underground, but its home has been envisaged and presented in different ways during human history, depending on the cultural and historical circumstances. The subterranean fauna was not known in traditional culture in the sense of scientific knowledge, and the cave environment had strong mythological elements, mostly as a hellish place void of life.

Once upon a time, the most famous resident of the underworld in the northern part of the Dinaric Karst was Jure Grando. During his lifetime, he was an exemplary man from the town of Kringa. But after he died, Grando would rise from his grave and sow terrible fear all over Istria province. When he knocked at night on someone's door, the next day a dead person would be found there. Jure Grando was a prototype vampire. In 1672, local citizens finally disposed of him: his body was dug up during a special ceremony, but when the chief of the police cut off his head, Grando let out a scream and blood filled the grave. Peace finally returned to Kringa after Grando was decapitated. (Valvazor, 1969).

For modern educated people, this picture of the underground world must have been strange and weird; but for the traditional world that lives in various modifications up to now, caves are reserved for beings that have almost nothing in common with today's subterranean fauna. According to ethnological origins (Bajuk, 2012), the real master of the underworld is "kača" - locally called snake. For Old Slavs, snakes were sacred animals - the guardian of the front door of the house and the soul of ancestors (Bajuk, 2012). Some forms of remembrance of a holy snake are kept in numerous places. In Popovo Polje (Bosnia and Hezegovina, B\&H), a belief existed until the mid $20^{\text {th }}$ century that a snake cannot be killed because it always comes back to life (Ivanišević, 2001, 2019).

In South Slavic languages, the word snake originated from the term ground. Therefore, the snake was quite a normal subject for the underworld, but the same underworld was also the origin and dwelling place for dragons (Skok, 1971-1974). Some say dragons originate from the snake, but a special kind of snake. It can have seven heads, it may grow wings and become a winged serpent, a winged horse, or a winged ox. It lives in the clouds and in caves. There are many caves named after dragon (in Slavic languages zmaj is dragon) For example, an "immense large pit" Zmajevica on the hill of Klisura in Popovo Polje (B\&H) (Mihajlović, 1890). There are numerous medieval tombstones, "stećci," with carved, stylized images of dragons. They bear witness that dragons were a significant part of the traditional lore.

Speleological features, especially springs, in old Slavic mythology usually meant source of life, and they were often places of worship. Women visiting Trbuhovica, the highest spring in Lubljanica Basin in Slovenia and Croatia , "did so to receive the gift of life." Today we would say to treat their infertility.

Moreover, it was believed that Trbuhovica spring literally brings babies. For a long period of time, the peasants of Babno Polje, placed on that basin, told their children that they were brought by the water (Pleterski and Šantek, 2012). Sometimes adults used to scare young children by telling them that Trbuhovica will also take them (Pleterski and Šantek, 2012). In a way, it was a continuation of the ancient belief that spring openings are the place through which you will reach another world. In essence, Trbuhovica was a two-way door between two worlds. Life comes through it into this world and finally leaves through it for another world or the afterlife. Trbuhovica is, in fact, the site of one of the three major deities of ancient Slavs: Mokoš or Baba, which means Mother Earth. Mokoš is the mistress of the house at the door (Katičić, 2011).

Why such a big difference between the underworld of Jure Grando and the old Slavs? This change was a result of the spreading of a new religion, Christianity. By accepting Christianity, Eve's serpent was equated with the devil or Satan (Bajuk, 2012), while early Christian iconography sometimes displays Jesus as a brass snake on a cross (Chevalier-Gheerbrant, 1994, after Bajuk, 2012). Therefore, women who drank water from Trbuhovica were now proclaimed as witches and were killed (Pleterski and Šantek, 2012). Caves became equated with hell, instead of giving new life.

Hence, everything that lived in the underground of the Dinaric Karst obtained an aura of evil, and the olm and snake were the only known physical members of that world at the time. The Christians had to relentlessly kill the dragon, in the manner of the legend of St. George and the Dragon, and a similar fate befell the human fish from Postojna Cave.

\section{Scientific History of the Olm}

In 1689, Johann Weikhard von Valvasor, the natural historian and pioneer of karst studies who acquainted us with Jure Grando, conveys statements of peasants from the Vrhnika area in Slovenia that they have seen a dragon's youngling in the Bela spring. Peasants explained its presence by the fact that the water in this spring appears twice a day, at midnight and around 9:00 a.m. When the water became high, the dragon becomes angry so he spits it out. A peasant had, he said, seen three young dragons in his life. A local mail carrier, who took one specimen home, described it to be around a span long (the width of a spread hand) and looking like a lizard (Valvasor, 1969).

Scientific knowledge of the olm began when peasants managed to catch living samples washed up at the Stična spring in Dolenjsko, Slovenia, and brought them alive to loannes Antonio Scopoli, who was a physician for the mercury mines in the nearby town of Idrija. Scopoli "received a hundred dragons" and was very thrilled with it. He put the samples into alcohol and sent them to numerous friends and colleagues, but he also made detailed studies of them including drawings and was preparing to publish an article about the discovery (Aljančič et al., 1993). 
However, Viennese zoologist J. N. Laurenti, who received one of Scopoli's samples through a nature lover, Sigismund Hochewart, described the discovery of a new species named Proteus anguinus in 1768. Its name shows that, even in science, this little creature could hardly be removed from the mythological context. The first part of the name is from Proteus, Greek god of the sea, and the second part, anguinus, means related to or resembling a snake, an animal with extremely strong mythological tradition.

Literature indicates that Laurenti's description was faulty and superficial and that it left a number of unresolved questions (Aljančič et al., 1993). Some of them were resolved by Scopoli himself in his much more thorough description that was published four years later in 1772. In it, he classified proteus as an amphibian. However, the famous Carl von Linné, father of modern biological taxonomy, did not want to include it in his Systema Naturae, the Linnaean system of taxonomy. According to Linnaeus, as did Laurenti, the animal was in a larval stage. It truly is, but as such, it becomes reproductively mature and as such it lives its entire life in this state, as Scopoli claimed correctly, but without success.

The name human fish, which is now dominant in the region, was recorded for the first time some forty years after it was scientifically described. In an unsigned article published 1807, Slovenian biologist Žiga Zois says that peasants from the Stina surroundings call it human fish and white fish. He also wrote down the name little white snake. Hence, it seems that the name human fish is the original traditional name, fitting for mythological and tourist interpretation. Over time, there will be several more artificially-coined names that became widely used (e.g., German olm or Slovenian močeril (Aljančič, 1989)).

At the beginning of the $19^{\text {th }}$ century, a new scientific interest for the olm arose, gaining global fame through several waves of research. Karl von Screibers of the Viennese Natural History Museum - at the time when Slovenia was part of the Austro-Hungarian Empire - studied its anatomy in detail. In 1800, he held lectures in London and Paris that the experts mark as epochal. As a result of these lectures, the olm won over the entire learned world and became one of the animals of most interest on the planet (Aljančič et al., 1993). Specimens were sent to all parts of the world; Screibers himself sent almost 300 of them.

This interest ignited the olm trade. From 1814, animals were sold at local inns in Postojna and sometimes outside of the cave. Guidebooks drew attention to their availability. Some were given to zoos, others were kept by amateur naturalists, some went to laboratories, and a few were even eaten. One was offered to Darwin for study (Shaw, 1999).

For the purpose of research, Zois started to breed olm in his apartment, followed by Screibers. In 1806, Screibers made a wax model of a nice specimen so the chroniclers attributed him the role of the "father of modern museum presentation of nature" (Aljančič et al., 1993). The research continued, and as early as 1850, curator of Viennese museum, L. Fitzinger, classified olm into seven species. However, the scientific community did not recognize this at the time. More recent research based on DNA methods confirmed that five populations of the olm differ enough genetically that they can be considered separate species (Gorički and Trontelj, 2006).

Two and a half centuries of olm research enabled exceptional insight into understanding its morphology, way of life, adaptation and functioning, even capturing its hatching on camera. It also brought about significant suffering of the $\mathrm{olm}$. They were caught en masse and subjected to experiments, such as keeping them in captivity for ten-years without food to determine how long they could survive. The olm became a metaphor for knowledge of the secrets of the underground, as well as transformation of our knowledge over time. Numerous books, research papers, and popular publications promoted the scientific perception of the olm and its underground world. Proteus has been so well researched that there is no need to link it with mythological dragons.

\section{Worldview Frame}

To this day and despite the breadth of research, public perception of the Dinaric Karst and reference to the olm as a mythological creature continues, which has no scientific corroboration:

1. 1. Mythological image of the olm as a "dragon." Truly, it is not as fearsome as its ancestor seems to be, it is more of a pet name. Its underground habitat is steeped in folklore and is dramatized as the origin of fear.

2. 2. An image of animal species that is in fact a "star" from the show business world. On the Postojna Cave web page, proteus is said to be a star amongst inhabitants of the cave. On millions of posters, flyers, and other media, for over a century, olm has had the starring role as a photo model for tourists, which attracts hordes of people. There is little discussion of other taxa - and there are over 80 species in Postojna Cave — apart from the star.

3. 3. More recently, the olm is often associated with clean water. In areas where the olm lives, the water is still environmentally sound, so an important characteristic of proteus is that it has become a bio-indicator of relative environmental health.

These three functions of the olm indicate that naming of this underground animal is more than a means of persuasion and shows the way we come to socially construct and know our natural world. That language is epistemic - it is how we come to know, and thus becomes central to the creation of our reality. Within this system of study, symbols and language are conceived of as perceptual lenses (Oravec and Clarke, 2004) 
These three functions well illustrate the dominant worldviews with which people have observed the world through history. There are several classifications (e.g., Capra 1982; Merchant 1998; Geiger 2009), however, among them, the most suitable for our use is the division (1) traditional, pre-modern or organic, (2) modern, rational or mechanistic, and (3) postmodern, environmental or holistic.

The earliest worldview is traditional or organic. It provides a mythologized image of the world, and according to this view, the visible world is only the expression of spirits or deities and the entire world is connected into one organic entirety. In it, caves are doors to another world. Human fish was actually a dragon. Home snake is a spirit of our ancestors or an expression of evil.

The second worldview is rational, modern, or industrial. It is based on the perception of the world as understandable through the principles of science. Accordingly, knowledge must be explainable and verifiable. It gradually introduced geology, geophysics, hydrogeology, speleology, biology, etc. into the underworld, using conventional systems of description, calculation and reasoning. Max Weber claims that the task of science is the disenchantment of the world (Weber, 1946). Rational sciences largely expelled the many mythological beings from the underground. However, different worldviews influence the mix of different content under this perspective. They primarily depend on socially influenced circumstances, but also on numerous individual inclinations.

The third worldview is postmodern or environmental. It sees scientific data through the living community in relation to the non-living world. An essential component of that image of the world is the awareness of the negative effects of humans on ecosystems. The olm fits in this worldview as a bio-indicator. This worldview opened the door to the subterranean fauna as a whole. In the last few decades, subterranean fauna have become increasingly visible and acceptable in the Dinaric Karst, thanks to this worldview. Not only have hundreds of scientific papers been written about the subterranean fauna of the Dinaric Karst, but the popular media coverage has been received by a large, worldwide audience.

\section{Media Contruction of Environment}

In the Dinaric Karst, cultural memory still connects the underground with mythological attributes. For instance, the snake still largely assumes its mythological aura. Each year, at the end of spring and beginning of summer, media in the Dinaric Karst area extensively reports on the danger of snakes. In the Dalmatia region, where snake bites are the most common, 5.2/100,000 inhabitants (Lukšić et al., 2006) are harmed annually, 0.4\% of these bites are lethal, showing that there is not really a factual foundation for the danger of snake bites, because almost the same number of people die in traffic accidents each year in Croatia, of which Dalmatia is one of the five regions. This danger can resonate only in a public in which mythological memory of snakes still vibrates.

Science fosters the principle of physical evidence that excludes the impact of spiritual values, which in market conditions, gives more weight to the principle of utility. We often hear: Science must serve the economy. How could these small subterranean animals be useful in the dominant model of a market economy in which the external attractiveness is one of the most important characteristics of a good? Proteus has become a photogenic model in the tourist cave, enveloped in a mythological fog: "miracle of the underworld." It has become an important part of the tourist attraction, luring almost a million visitors to the cave in the most successful years.

On the other hand, our subconscious resists rationalization of life (Barešin, 2016), and taking into account the underworld, creates subversive phenomena such as dragons or vampires. The market economy relates them to contemporary myths for its commercial value. Many films were made and books written on Count Dracula. This is partly why many "consumers" of these products associate innocent bats with blood-thirsty vampires. Other underground species are scarcely known by the general public. It confirms what is well-known in environmental communication: the environmental issues are recognized by the public only when media and public forums present them as matters of public and political significance (Hansen, 2015). The media image of reality is a social construct.

Who made this construct and how? Here is an example. Primary definers in news coverage of environmental issues on British and Danish television (Hansen, 1991) are 23\% authorities on the subject matter, 21\% governmental representatives, $17 \%$ independent scientists, and $6 \%$ represent environmental groups.

To identify the environmental problems in the public arena as such, the media and public forums need to present them as issues of public and political importance. Therefore, environmental problems only become recognized, per se, through the process of public claims-making (Hansen, 2015), and the result depends on their balance of power.

With regard to the sources on which the articles on hatching of the olm relied, as well as the sources for images of proteus, it is obvious that they are largely based on the data obtained from the officials at Postojna Cave. Similarities can be found with the official web pages of the Cave, which are written with respect to the rules of a tourist guide (i.e., marketing of this tourist attraction).

Olms have been intriguing people for centuries, the news about them reaching even the far corners of the region back in the day. This intrigue was mainly owing to people's vivid imagination, the mystery surrounding the species, and the polymath Johann Weikhard von Valvasor, who wrote about the dragon living the depths of the caves between Postojna and Vrhnika (Wonderland Stories, 2017; Postojnska-jama, 2017) (Figs. 3A, 3B). 


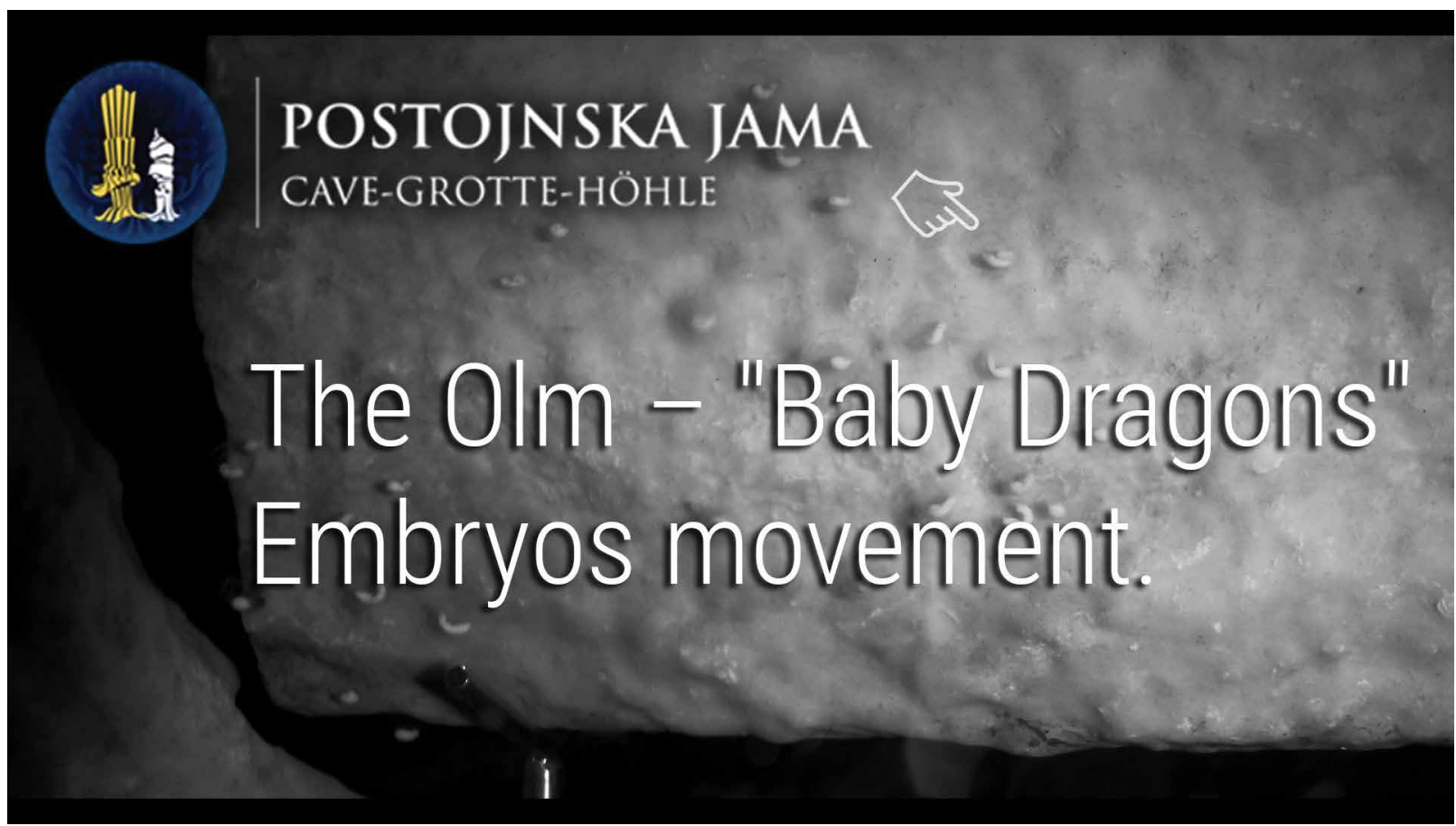

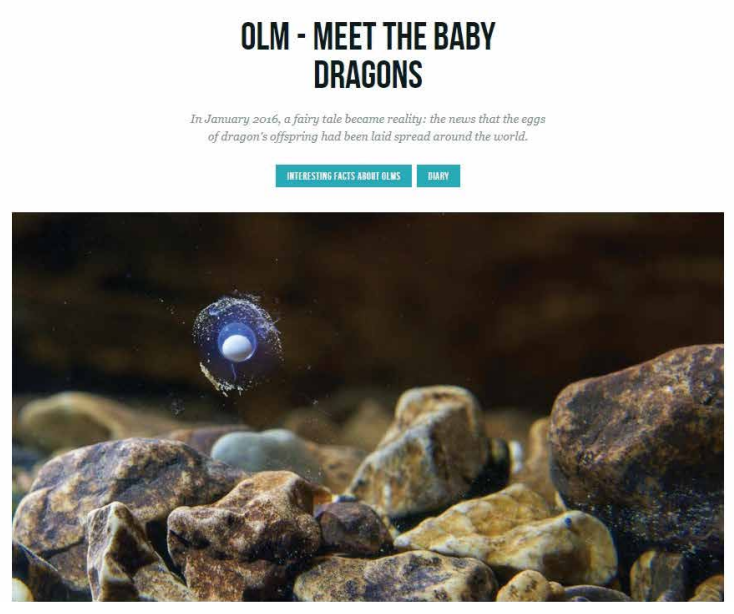

14. POSTOJNSKA JAMA
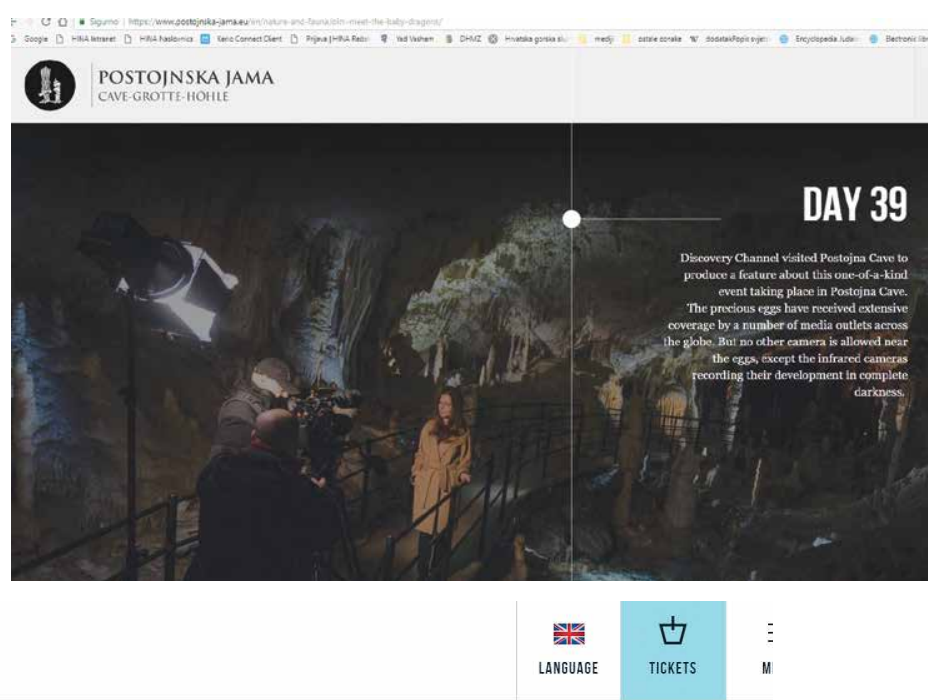

\section{VIVARIUM PROTEUS}

The undisputed star among Postojna Cave's inhabitants is the olm,

Proteus anguinus, however, the Karst underground world is

inhabited by mumerous other interesting inhabitants. According to

explorers' estimates, Postojna Cave is home to more than 150 animal

species. You can get to know some of the most interesting ones in

more detail at Vivarium Proteus.

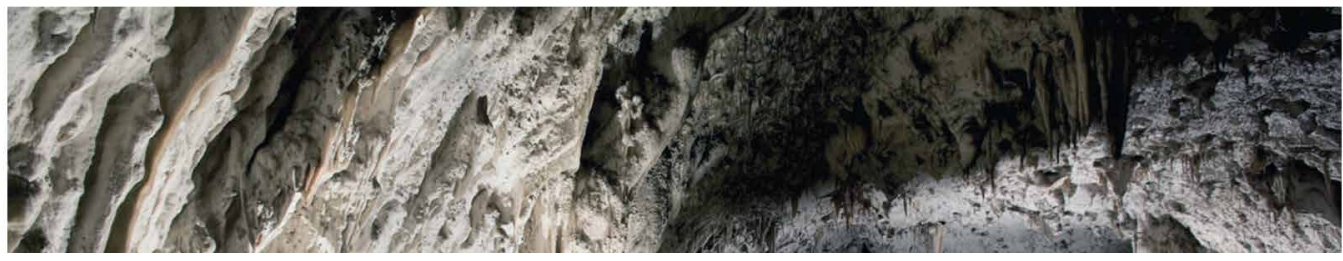

Figure 3A-3D. Presentation of the proteus and proteus hatching by the management of the Postojna Cave (screenshots of the website). 


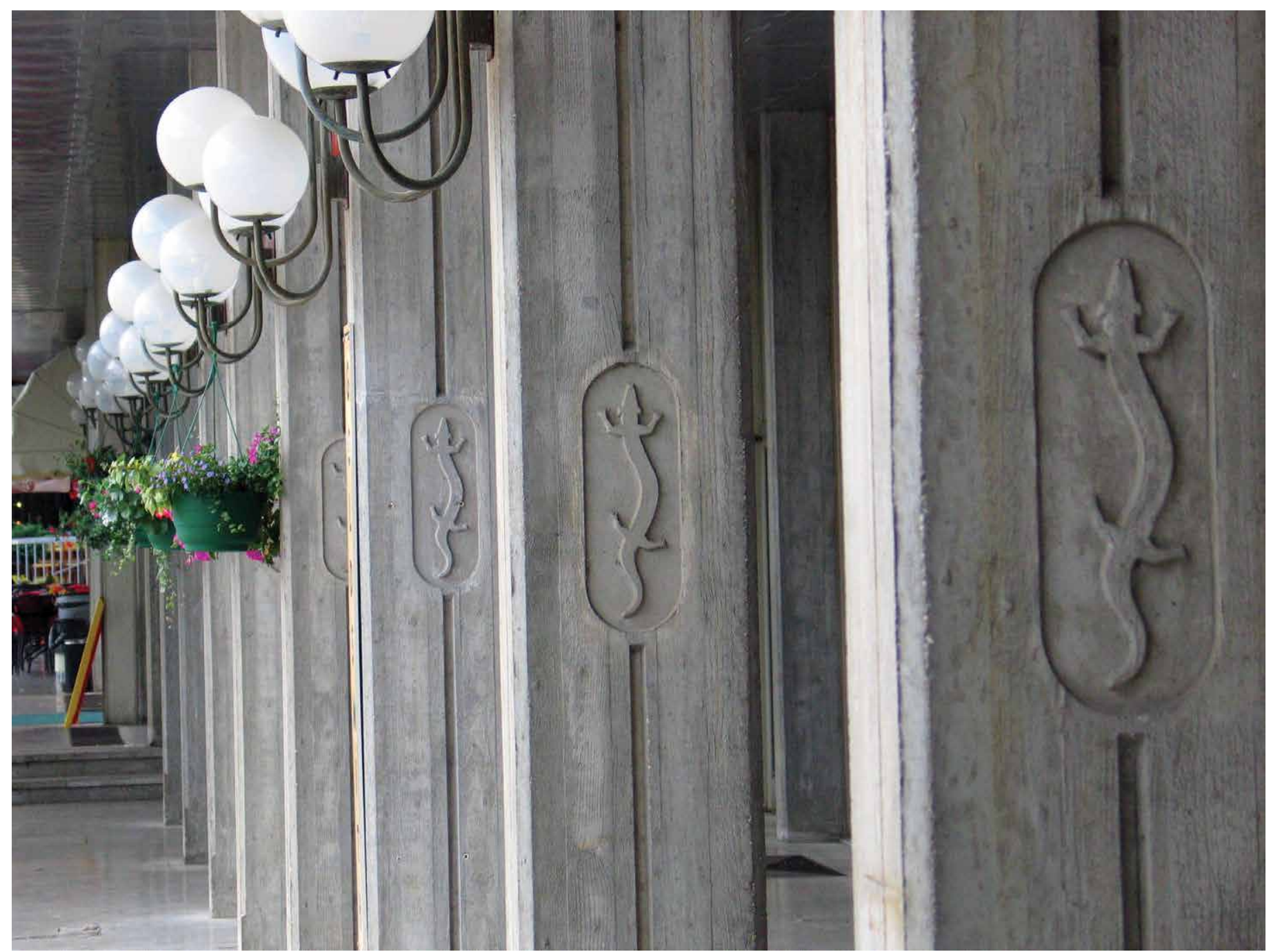

Figure 4. The figure of olm applied to the pillars in front of the Jama (Cave) Hotel in Postojna.

The precious eggs have received extensive coverage by media outlets across the globe. But the mystery remains hidden in the darkness, recorded only by means of an infrared camera (Fig. 3C).The undisputed star among Postojna Cave's inhabitants is the olm, Proteus anguinus; however, the karst underground world is inhabited by numerous other interesting inhabitants (Postojnska-jama, 2020) (Fig. 3D).

Actually, very few authors of the articles reviewed here looked for additional sources beyond the official Postojna Cave information. Thus, it is no wonder that some sentences in the articles are phrased as if they are part of Postojna Cave publicity material. It should be said, in this article I do not venture into a detailed analysis of cultural and historical aspects of the proteus's heritage, which is growing into elements of the national identity. I will only recall the various proteus prints on buildings (Fig. 4) and coins (Fig. 5). During the period in which a rational worldview gained strength, olm was mostly promoted in Postojna Cave, relying on scientific sources, on interest of a robust tourist industry, and on the appetite of the public. Tour guides in Postojna Cave played an extremely important role in interpretation of the underground, especially its living world, including the dominant elements of different worldviews. This tourist model of presentation is still dominant in the general public. For a long time, the olm has stopped being an epistemological issue and is now more predominantly a matter of media construction of the environment. A more careful interpretation of this phenomena requires more detailed research.

\section{CONCLUSION}

Historical analysis of the olm is a clear example of what usually happens in the natural sciences. It is traditionally believed that after a specific scientific discovery the knowledge reaches all the people in its integral form and that the public then creates a "real" image of the world based on that knowledge. Knowledge is an important element in the construction of the image of the world, but it is not the only image. This image is determined by different historical, political and cultural cir- 


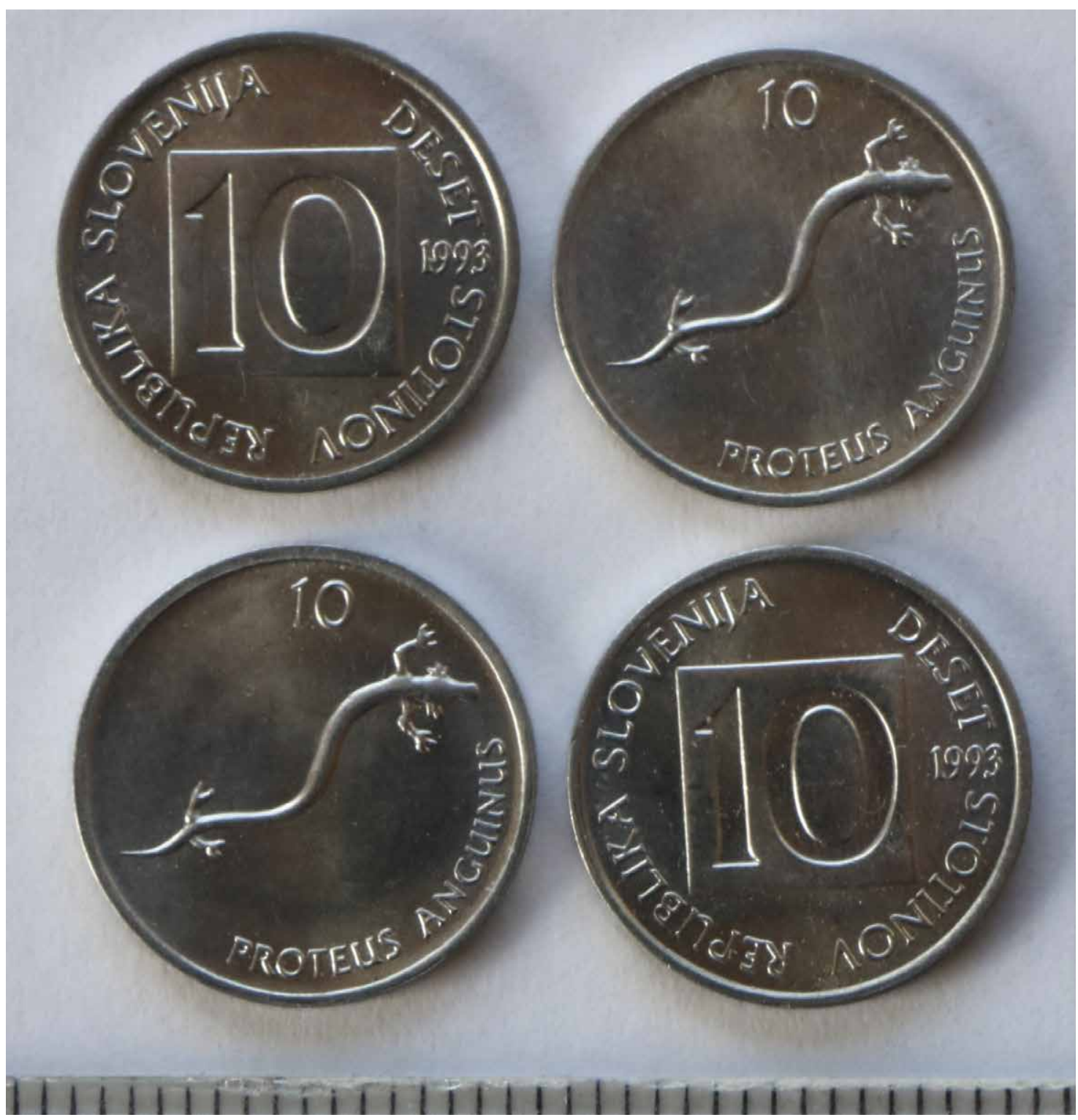

Figure 5. Proteus-coin. cumstances, as well as the social interests of the people who constructed it. The example of $s$ proteus shows that the tourist guides in the Postojna Cave were a significant factor in forming this image. They contributed to the fact that this image, besides the basic scientific facts, contains emphasized elements of a brand with a market value, i.e. as a tourist attraction. Further research is needed for more detailed answers that would cast more light into the connection between $s$ proteus as a natural phenomenon and its public image. Thus, the results of this article should be considered in further research on caves and their public perception for purposes of their management and commercialization.

\section{ACKNOWLEDGMENTS}

My gratitude goes to Maja Kranjc from Ljubljana and Gregor Aljančič from Kranj (Slovenia) for their support with the article and also to Anđela Štefanović and Nada Beroš from Zagreb (Croatia) for their help in translation. Figure 1 photo from Andrej Mihevc and Figure 5 from Andrej Kranjc.

\section{REFERENCES}

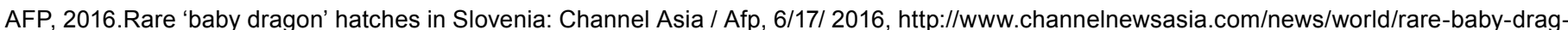
on-hatches-in-slovenia-7955440.Aljančič, M., 1989, "Človekova" ribica in druga imena naše jamske dvoživke: [Slovenian: The "human" fish and other names of our cave amphibians]: Proteus v. 51 (1988-1989), p. 365-366.

Aljančič, M., Bulog, B., Kranjc, A., Josipovič, D., Sket, B., and Skoberne, P. 1993, Proteus, skrivnostni vladar kraške teme: [Slovenian: Proteus, the mysterious ruler of the karst darkness]: Založba Vitrum.

Anonymous, 2016. In Slovenia, rare "dragons" are born in an aquarium: Thai Tribune, 3/6/2016, http://thaitribune.org/contents/detail/339?content_id=20500\&rand=1465018376

Bajuk, L., 2012, Kača. in Marjanić, S. and Zaradija Kiš, A. eds., Književna životinja - kulturni bestijarij, II. Dio: [Croatian: Literary Animal - Cultural Bestiary, II part]. Zagreb: HSN i IEF, p. 165-192.

Barešin, S., 2016, Vampiri u popularnoj i pučkoj kulturi: Croatian: Vampires in popular and folk culture]: Ethnologica Dalmatica, v. 23 no.1, p. 5-14.

Capra, F., 1982, The Turning Point: Science, Society, and The Rising Culture: Bantam Books Toronto, New York, London, Sydney, Auckland. 464 p.

Crist, M., 2016. What's behind Slovenia's love affair with a salamander?: The New Yorker, 4/25/2016, https://www.newyorker.com/tech/elements/ whats-behind-slovenias-love-affair-with-a-salamander. 
Culver, D. C., and Sket, B., 2000, Hotspots of subterranean biodiversity in caves and wells. Journal of Cave and Karst Studies, v. 62, p. $11-17$.

Fleur, N. St., 2016. In a Slovenian cave, hoping for a batch of baby "Dragons": The New York Times, 5/2/2016, https://www.nytimes. com/2016/02/06/science/in-a-slovenian-cave-hoping-for-a-batch-of-baby-dragons.html

Fox News, 2016. Rare 'dragon eggs' hatch in Slovenian cave: Fox News, 6/2/2016, http://www.foxnews.com/science/2016/06/02/rare-dragoneggs-hatch-in-slovenian-cave.html

Geiger, M., 2009, S onu stranu monkulture: [Croatian: On the other side of monculture]: Antibarbarus, Zagreb.

Gili, E., 2016. Saving the Balkan 'baby dragon': DW, 3/22/2016, http://www.dw.com/en/saving-the-balkan-baby-dragon/a-19133220

Gorički., Š., and Trontelj, P., 2006, Structure and evolution of the mitochondrial control region and flanking sequences in the European cave salamander Proteus anguinus: Gene v. 378, p. 31-41, https://doi.org/10.1016/j.gene.2006.04.016.

Graham, K., 2015. Postojna Cave - The underground world of 'human fish': http://www.digitaljournal.com, 8/23/2015, http://www.digitaljou rnal. com/life/travel/the-dragon-s-offspring-undisputed-star-of-postojna-cave/article/441883

Graham, K., 2016. In a Slovenia cave a tense wait goes on for the birth of a dragon: http://www.digitaljournal.com, 2/29/2016, http://www.digitaljournal.com/science/in-a-slovenia-cave-a-tense-wait-goes-on-for-the-birth-of-a-dragon/article/458924

Hansen, A., 1991, The media and the social construction of the environment: Media, Culture \& Society, v. 13, p. 443-458, https://doi. org/10.1177/016344391013004002.

Hansen, A., 2015, Communication, media and the social construction of the environment: in Hansen, A. and Cox, R., eds. The Routledge Handbook of Environment and Communication. Routledge, Abingdon, Oxon, New York, p. 26-38,

Hrala, J., 2016. Slovenia's ultra-rare 'Dragon Eggs' are hatching as we speak: www.sciencealert.com, 6/2/2016, https://www.sciencealert.com/ slovenia-s-ultra-rare-dragon-eggs-are-hatching-as-we-speak.

Ivanišević, P., 2001, Doživljaji i uspomene: [Croatian: Experiences and memories]: Beograd: Arhiv Srpske akademije nauka i umetnosti; Novi Sad: Arhiv Vojvodine, p. 359.

Katičić, R., 2011, Gazdarica na vratima: [Croatian: The landlady at the door]: Ibis grafika, Katedra Čakavskog sabora Općine Mošćenička Draga, Matica hrvatska. Zagreb - Mošćenička Draga, p. 283.

Kranjc, A., 2003, Dinaric Karst. in Gunn, J., ed., Encyclopedia of Caves and Karst Science, Fitzroy Dearborn. New York, p. $287-289$.

Lukšić, B., Bradarić, N. and Prgomet, S., 2006, Venomous snakebites in southern Croatia. Collegium antropologicum, v. 30, p. 191-197.

McKie, R., 2017. How Slovenia is helping its 'baby dragons': The Guardian, 8/27/2017, https://www.theguardian.com/environment/2017/aug/27/ slovenia-baby-dragons-postojna-salamaders-olms-proteus-anguinus.

Merchant, C., 1998, The Death of Nature: Woman, Ecology, and the Scientific Revolution“ Harper and Row Publishers, San Francisco. 348 p.

Mihajlović, H., 1890, Manastir Zavala i Vjetrenica pećina: [Croatian: Zavala Monastery and Vjetrenica Cave]: Glasnik zemaljskog muzeja, II, Sarajevo, p. 130-143.

Oravec, C. L. and Clarke, T, 2004, Naming, interpretation, policy, and poetry: in . Senecah, S.L., ed. 2004. Environmental Communication Yearbook, Mahwah, NJ: Lawrence Erlbaum Associates, v. 1, p. 1-14, https://doi.org/10.1207/s15567362ecy0101_1.

Photopoulos, J., 2016. First 'baby dragons' hatched in captivity reach adolescence: New Scientist, 9/30/2016, https://www.newscientist.com/ article/2107670-first-baby-dragons-hatched-in-captivity-reach- adolescence/.

Pleterski, A. and Šantek, G. P., 2012, Baba Babnega polja [Slovenian:The grandmother (baba) of Baba Polje]: Studia Mythologica Slavica,v. 15, p. 63-77, https://doi.org/10.3986/sms.v15i1.1565.

Postojnska-jama, 2017. https://www.postojnska-jama.eu/en/nature-and-fauna/olm-meet-the-baby-dragons/. [accessed: July 2017]

Postojnska-jama, 2020. Vivarium. https://www.postojnska-jama.eu/en/attractions-in-the-park/vivarium/

Shaw, T.R., 1999, Proteus for sale and for science in the $19^{\text {th }}$ Century: Acta Carsologica, v. 28, no. 1, p. 329-304, https://doi. org/10.1023/A:1008916601121.

Šimičević, V. 2012, Saving the olm: speleologists and divers looking for habitats, Novi list (Rijeka, Croatia).[in Croation]. http://www.novilist.hr/ Znanost-i-tehnologija/Znanost/Spasavanje-covjece-ribice-speleolozi-i-ronioci-u-potrazi-za-stanistima. [accessed July 2016].

Sket, B., 1999, The nature of biodiversity in hypogean waters and how it is endangered: Biodiversity and Conservation, v. 8, p. 1319-1338, https://doi.org/10.1023/A:1008916601121.

Skok, P., 1971-74, Etimologijski rječnik hrvatskoga ili srpskoga jezika (1-4): Croatian: Etymological Dictionary of the Croatian or Serbian Language v. 1-4]: Zagreb: Jugoslavenska akademija znanosti i umjetnosti.

Tan, A., 2016., Rare 'baby dragons' recorded hatching in ancient Slovenian cave: ABC news, 3/6/2016, http://abcnews.go.com/International/rare-baby-dragons-recorded-hatching-ancient-slovenian-cave/story?id=39586501.

Valvasor, J. V., 1969,. Valvasorjevo berilo - slava vojvodine Kranjske, Ljubljana: [Slovenian:Valvasor's Reader — the glory of the Duchy of Carniola]: Mladinska knjiga, 603.

Večernji list, 2017. The message of a human fish from Ljubuskog. https://www.vecernji.hr/vijesti/poruka-covjecje-ribice-iz-ljubuskog-825620

Veness, S., and Veness, S., 2015. Where the 'human fish' lurks: BBC, 8/19/2015, http://www.bbc.com/travel/story/20150714-where-the-humanfish-lurks

Vrdoljak, I., 2016. Čovječja ribica donijela pet mladunaca [Croatian: The human fish brought five cubs]: Al Jezeera Balkans, 6/9/2016, http://balkan.aljazeera.net/vijesti/covjecja-ribica-donijela-pet-mladunaca,

Webb, J. 2016. Olm eggs: First two Slovenian 'dragons' emerge: BBC, 6/2/2016, http://www.bbc.com/news/science-environment-36418545.

Weber, M., 1946, From Max Weber: Essays in Sociology: New York, Oxford University Press. http://anthropos-lab.net/wp/wp-content/uploads/2011/12/Weber-Science-as-a-Vocation.pdf

Wonderland Stories. 2017. https://www.postojnska-jama.eu/en/nature-and-fauna/olm-meet-the-baby-dragons/? [accessed Feb. 2017] 